\title{
Hadith Studies in Malaysia: A Meta-Analysis Approach
}

Khalilullah Amin Ahmad, Fathullah Asni, Solahuddin Abdul Hamid \& Mohd Nizho Abdul Rahman

To Link this Article: http://dx.doi.org/10.6007/IJARBSS/v11-i10/10998

DOI:10.6007/IJARBSS/v11-i10/10998

Received: 02 August 2021, Revised: 24 August 2021, Accepted: 20 September 2021

Published Online: 05 October 2021

In-Text Citation: (Ahmad et al., 2021)

To Cite this Article: Ahmad, K. A., Asni, F., Hamid, S. A., \& Rahman, M. N. A. (2021). Hadith Studies in Malaysia: A Meta-Analysis Approach. International Journal of Academic Research in Business and Social Sciences, 11(10), 108-120.

\section{Copyright: (c) 2021 The Author(s)}

Published by Human Resource Management Academic Research Society (www.hrmars.com)

This article is published under the Creative Commons Attribution (CC BY 4.0) license. Anyone may reproduce, distribute, translate and create derivative works of this article (for both commercial and non-commercial purposes), subject to full attribution to the original publication and authors. The full terms of this license may be seen at: http://creativecommons.org/licences/by/4.0/legalcode

\section{Vol. 11, No. 10, 2021, Pg. 108 - 120}

Full Terms \& Conditions of access and use can be found at http://hrmars.com/index.php/pages/detail/publication-ethics 


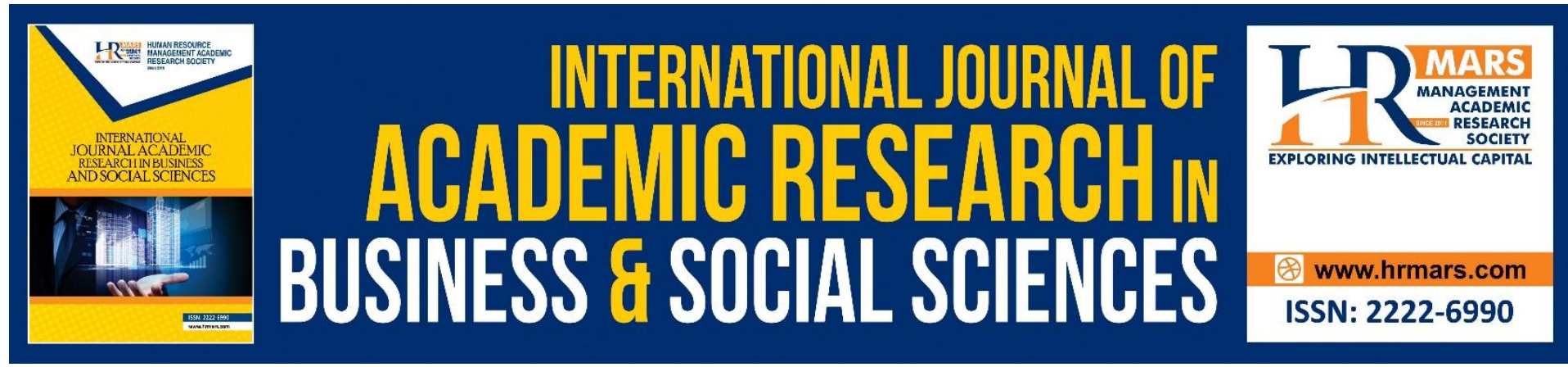

\title{
Hadith Studies in Malaysia: A Meta-Analysis Approach
}

\section{Khalilullah Amin Ahmad ${ }^{1}$, Fathullah Asni², Solahuddin Abdul Hamid $^{3}$ \& Mohd Nizho Abdul Rahman ${ }^{4}$}

${ }^{1}$ Faculty of al-Quran and al-Sunnah, Kolej Universiti Islam Perlis (KUIPs), ${ }^{2}$ Faculty of Islamic Studies, Kolej Universiti Islam Perlis (KUIPs), ${ }^{3}$ UUM College Of Arts And Sciences, Universiti Utara Malaysia (UUM), ${ }^{4}$ UUM College Of Arts And Sciences, Universiti Utara Malaysia (UUM)

Email: amin@kuips.edu.my, fathasni90@gmail.com, solah@uum.edu.my, nizho@uum.edu.my

\begin{abstract}
Hadith studies have been going on since the times of the Prophet Muhammad (PBUH) with various methods. The teaching and learning (T\&L) of hadith is an issue that researchers often study to enhance the level and quality of T\&L itself. This is because there is the fact that the hadith lecturers are not creative in teaching, lack pedagogical skills and do not apply the latest innovative methods in the process of T\&L. This meta-analysis was conducted to explore previous studies on the science of hadith studies in Malaysia from 2010 to 2021. Although there are many studies on hadith studies, there are still few studies in Malaysia. Based on the search, only seven studies are published on the science of hadith studies in Malaysia. The analysis conducted for these seven studies found certain elements in explaining the science of hadith studies in Malaysia. These studies also found that science of hadith studies in Higher Educational Institutions involved. In addition, this study also focused on the main findings of each study conducted. This study also examines the methodology of the study used. The findings of this study are intended to help future research in the science of hadith studies in Malaysia. In addition, this analysis also suggests some ideas for further research.
\end{abstract}

Keywords: Hadith Studies, Meta-Analysis, Quantitative Approaches, Qualitative Approaches

\section{Introduction}

After the Quran, Hadith is the second most important source of Islamic instruction (Asni, 2017; Abdullah et al., 2020). In the time of the Prophet PBUH, hadith was taught and learned in several ways that aided the Companions (al-sahabah) in memorising the hadith that had been conveyed to them. The several methods employed in teaching hadith including storytelling, lectures, actions, or acts, questioning, carrying out activities, and talaqqi (small group lesson) (al-Azhari, 2017). The Prophet also used teaching aids such as mind map sketches to help the Companions understand some hadith by providing a clear vision and interpretation (Saleem \& Iqbal, 2019).

After the death of the Prophet, the teaching and learning of hadiths grew with the dissemination of hadith writings by Muslim scholars worldwide. In Malaysia, hadith 
knowledge has been developed and studied at all levels of education, starting from pre-school to higher education. Educators use a variety of teaching and learning approaches, including teacher-centred teaching, student-centred teaching, brainstorming, sketching, storytelling, and many others. In Malaysia, one of the Prophet's methods of communicating hadith, known as talaqqi, is taught in sekolah pondok (hut school) and maahad (Islamic religious secondary school), to uphold the Prophet's teaching method. The efficiency and effectiveness of the talaqqi method cannot be disputed because it is the most successful technique of stressing the teacher-centred learning process (Eissa \& Khalid, 2018).

\section{Research Background}

Although there are many studies on the science of hadith studies, there are still few studies in Malaysia. Based on the search, only seven studies are published on the science of hadith studies in Malaysia. Therefore, this meta-analysis was conducted to explore some aspects of previous studies on the science of hadith studies in Malaysia. Based on these requirements, this study was conducted to answer the following research questions:

i. What are the main themes of the study related to the science of hadith studies in Malaysia?

ii. What are the elements of the science of hadith studies in Malaysia?

iii. What research methods have been used to conduct research on the science of hadith studies in Malaysia?

iv. What are the main findings from the study on the science of hadith studies in Malaysia?

\section{Literature Review}

In Yabi et al (2017) study, the teaching approaches that can be applied to the Ulum Hadith subjects offered at higher education institutions in Malaysia and identifying opportunities to reinforce the Ulum Hadith teaching approach. This study used document analysis and articles related to it. As a result of this research, they have proposed six approaches in the teaching and learning of the Ulum Hadith subjects in higher learning institutions, namely lecturers should act as muallim, producing meaningful learning with student-centered teaching, using an eclectic approach that combines all or part of the features of a method into new methods, using tables and diagrams in learning, mastering the four pedagogical skills of the Prophet, and implementing active learning.

The second study was a study by Sobali et al (2013). The purpose of the study is the need for teaching and learning Ulum Hadith with the method of matan memorization or simply using the syllabus book to understand students. The study conducted by the USIM lecturer found that the teaching method of Ulum Hadith requires memorisation to ensure that students can understand Ulum Hadith in addition to the use of textbooks that can further strengthen the understanding of the syllabus.

While the third study is a study by Ahmad and Deraman (2011). The purpose of this study is to highlight the effort to write a book Ulum Hadith using mind maps in the form of tables and diagrams that aims to overcome the problems of Ulum Hadith courses that are considered complex and difficult to understand so that students are not interested in learning it.

The fourth study was a study by Abd Rahman and Asbullah (2012). The purpose of the study is to review the position of hadith studies in IPTA/S in Malaysia. The researchers found that there is a paradigm shift needed in the process of teaching and learning hadith so that it 
not only gets its rightful place among Muslims, but also conforms to the method that the scholars of hadith have outlined.

Overall, the teaching and learning of Ulum Hadith need to be in line with the needs and improvements of both the quality of teaching of lecturers and the learning methods of students so that the knowledge of hadith can be mastered well in line with current needs.

\section{Research Methodology}

This study uses a meta-analysis design, a secondary study form by identifying, exploring, and interpreting all relevant studies related to a topic domain (Webster \& Watson, 2002). To narrow down the scope of previous research on science of hadith studies in Malaysia, several databases have been selected, namely (i) Scopus (www.scopus.com); (ii) Science Direct (www.sciencedirect.com) and (iii) Research Gate (www.researchgate.com). All three of these databases were selected because they could increase the chances of finding relevant literature.

Internet search engines such as Google Scholar and Google Search are also used to get a broader search on topics. Keywords such as "pengajian ulum hadith di Malaysia" (in Malay) and "science of hadith studies in Malaysia" were used to search the article. Among the criteria for selecting articles to analyse are (i) research in the field of science of hadith studies, (ii) research data collected among Higher Educational Institutions and (iii) research from 2010 to 2021. Finally, a total of seven articles were identified that met the set criteria. Table 1 shows a list of research articles related to hadith studies in Malaysia that have been systematically analysed to answer predefined research questions. 
Table 1: Selected articles for the science of hadith studies in Malaysia

\begin{tabular}{|c|c|c|c|c|}
\hline & Reseachers & Research Topic & $\begin{array}{l}\text { Journal / } \\
\text { Proceedings }\end{array}$ & Year \\
\hline 1 & $\begin{array}{l}\text { Amiruddin Mohd } \\
\text { Sobali, Norazman } \\
\text { bin Alias, Zulhilmi } \\
\text { bin Mohamed Nor } \\
\text { \& Ahmad Sanusi } \\
\text { Azmi }\end{array}$ & $\begin{array}{l}\text { Methodology of Studying Ulum Al- } \\
\text { Hadith: Between the Requirements of } \\
\text { Memorisation of Matan (Mustalah Al- } \\
\text { Hadith) with Modern Teaching }\end{array}$ & $\begin{array}{l}\text { Jurnal Al- } \\
\text { Quran Dan } \\
\text { Al-Hadith, } \\
\text { Seminar } \\
\text { MUSNAD }\end{array}$ & $\begin{array}{l}2011 \\
\text { Teaching Hadith } \\
\text { Science at USIM }\end{array}$ \\
\hline 2 & $\begin{array}{l}\text { Thuraya Ahmad \& } \\
\text { Fauzi Deraman }\end{array}$ & $\begin{array}{l}\text { The Use of Tables and Diagrams in } \\
\text { Writing for the Subject of Mustalah Al- } \\
\text { Hadith }\end{array}$ & $\begin{array}{l}\text { Jurnal Al- } \\
\text { Quran Dan } \\
\text { Al-Hadith, } \\
\text { Seminar } \\
\text { MUSNAD }\end{array}$ & $\begin{array}{l}2011 \\
\text { Writings of } \\
\text { Middle Eastern } \\
\text { Scholars and } \\
\text { Western } \\
\text { Orientalists }\end{array}$ \\
\hline 3 & $\begin{array}{l}\text { Shumsudin Yabi, } \\
\text { Syulhanif Kadri, } \\
\text { Zulhilmi Mohd Nor, } \\
\text { Mohd Fauzi Mohd } \\
\text { Amin }\end{array}$ & $\begin{array}{l}\text { Teaching the Science of Hadith } \\
\text { Transmission Course in Public Higher } \\
\text { Educational Institutions: A Literacy } \\
\text { Review of Current Teaching } \\
\text { Approaches }\end{array}$ & $\begin{array}{l}\text { Journal of } \\
\text { Ma'alim al- } \\
\text { Quran wa al- } \\
\text { Sunnah }\end{array}$ & $\begin{array}{l}2017 \\
\text { Ulum Hadith in } \\
\text { IPTA in Malaysia } \\
\text { (FPQS) }\end{array}$ \\
\hline 4 & $\begin{array}{l}\text { Mohd. Muhiden } \\
\text { Abd. Rahman \& } \\
\text { Abd Latiff Abd } \\
\text { Haliff }\end{array}$ & $\begin{array}{l}\text { The Reality of Al-Hadith Studies in } \\
\text { Middle Eastern Institutions of Higher } \\
\text { Learning: An Analysis }\end{array}$ & $\begin{array}{l}\text { Jurnal Al- } \\
\text { Quran Dan } \\
\text { Al-Hadith, } \\
\text { Seminar } \\
\text { MUSNAD }\end{array}$ & $\begin{array}{l}2011 \\
\text { Universities in } \\
\text { the Middle East } \\
\text { (UAE, Egypt, } \\
\text { Syria, Jordan, } \\
\text { Saudi Arabia, } \\
\text { Qatar) }\end{array}$ \\
\hline 5 & $\begin{array}{l}\text { Mohd Muhiden } \\
\text { Abd Rahman \& } \\
\text { Zainab Asbullah }\end{array}$ & $\begin{array}{l}\text { The Reality of Hadith Studies in Islamic } \\
\text { Higher Education Institutions: A Study } \\
\text { in Islamic Higher Education Institutions } \\
\text { in Malaysia }\end{array}$ & $\begin{array}{l}\text { Al-Basirah } \\
\text { Journal }\end{array}$ & $\begin{array}{l}2012 \\
\text { Institutions of } \\
\text { Islamic Studies in } \\
\text { Malaysia }\end{array}$ \\
\hline 6 & $\begin{array}{l}\text { Shumsudin Yabi, } \\
\text { Norhasnira } \\
\text { Ibrahim, Adnan } \\
\text { Mohamed Yusof, } \\
\text { Mohd Fauzi Mohd } \\
\text { Amin }\end{array}$ & $\begin{array}{l}\text { Students' Perception on Teaching and } \\
\text { Learning of Ulum Hadith: A } \\
\text { Comparative Study in Malaysian } \\
\text { Higher Public Educational Institutions }\end{array}$ & $\begin{array}{l}\text { Journal of } \\
\text { Xi'an Shiyou } \\
\text { University, } \\
\text { Natural } \\
\text { Science } \\
\text { Edition }\end{array}$ & $\begin{array}{l}2019 \\
310 \text { people in } \\
\text { USIM, UIAM and } \\
\text { UKM }\end{array}$ \\
\hline 7 & $\begin{array}{l}\text { Siti Mursyidah } \\
\text { Mohd Zin, Hamzah } \\
\text { Omar, Mohd Asri } \\
\text { Ishak, Mohd Norzi } \\
\text { Nasir \& Norhazlina } \\
\text { Omar }\end{array}$ & $\begin{array}{l}\text { The Influence of Mental and Emotional } \\
\text { Readiness on The Academic Excellence } \\
\text { of Learning Ulum Hadith Among } \\
\text { Students: A Case Study in KUIS }\end{array}$ & $\begin{array}{l}\text { Jurnal } \\
\text { Pengajian } \\
\text { Islam }\end{array}$ & $\begin{array}{l}2019 \\
\text { Six hadith } \\
\text { students at FPPI, } \\
\text { KUIS Selangor }\end{array}$ \\
\hline
\end{tabular}

\section{Findings}

The findings of this study are summarised into four sections according to the research question. The first section explains the characteristics of research themes related to the 
science of hadith studies in Malaysia. The second part explores the elements of the science of hadith studies in Malaysia. The third section explores the research methods used by researchers in their research on the science of hadith studies in Malaysia. The fourth section provides an overview of the main findings of the study.

RQ1: What are the main themes of the study related to the science of hadith studies in Malaysia?

According to the analysis conducted, there are three themes of the science of hadith studies in Malaysia: teaching methodology, student learning methods, and scope of teaching and learning in the science of hadith. Table 2 shows related themes study.

Table 2: Themes Study

\begin{tabular}{|l|l|l|l|}
\hline $\begin{array}{l}\text { Themes } \\
\text { Study }\end{array}$ & $\begin{array}{l}\text { Sub- } \\
\text { themes }\end{array}$ & $\boldsymbol{f}$ & Studies \\
\hline $\begin{array}{l}\text { Identifying } \\
\text { methodology } \\
\text { of teaching in } \\
\text { science of } \\
\text { hadith }\end{array}$ & $\begin{array}{l}\text { Method of } \\
\text { delivery }\end{array}$ & 3 & $\begin{array}{l}\text { Sobali, A. M., Alias, N., Nor, Z. M., \& Azmi, A. S. } \\
\text { (2011), Ahmad, T., \& Deraman, F. (2011), Yabi, } \\
\text { S., Kadri, S., Mohd Nor, Z., \& Mohd Amin, M. F. } \\
\text { (2017). }\end{array}$ \\
\hline $\begin{array}{l}\text { Exploring } \\
\text { learning } \\
\text { methods }\end{array}$ & $\begin{array}{l}\text { Self- } \\
\text { learning }\end{array}$ & 3 & $\begin{array}{l}\text { Abd Rahman, M. M., \& Asbullah, Z. (2012), Yabi, } \\
\text { S., Kadri, S., Mohd Nor, Z., \& Mohd Amin, M. F. } \\
\text { (2017), Zin, S. M. M., Omar, H., Ishak, M. A., } \\
\text { Nasir, M. N., \& Omar, N. (2019). }\end{array}$ \\
\hline $\begin{array}{l}\text { Exploring the } \\
\text { scope of } \\
\text { teaching and } \\
\text { learning }\end{array}$ & $\begin{array}{l}\text { Syllabus } \\
\text { Teaching } \\
\text { plan }\end{array}$ & 3 & $\begin{array}{l}\text { Abd Rahman, M. M., \& Abd Haliff, A. L. (2011), } \\
\text { Abd Rahman, M. M., \& Asbullah, Z. (2012), Yabi, } \\
\text { S., Kadri, S., Mohd Nor, Z., \& Mohd Amin, M. F. } \\
\text { (2017). }\end{array}$ \\
\hline
\end{tabular}

RQ2: What are the elements of the science of hadith studies in Malaysia?

Based on the analysis conducted, there are nine elements comprising seven elements of teaching methods in science of hadith, namely, teacher-centred teaching, memorisation of matan, use tables and diagrams, lecturers act as muallim, student-centred teaching, materialcentred teaching, eclectic approach, four pedagogical skills of the prophet and assessment methods.

While for the student learning methods, there are four elements, namely, student acceptance, mental preparedness, emotional and active learning. As for the theme of the scope of teaching and learning in the science of hadith, there are five elements: teaching aids, syllabus, core subject, textbook, and credit hour. Table 3 shows the related elements. 
Table 3: Elements of the science of hadith studies in Malaysia

\begin{tabular}{|c|c|c|c|}
\hline $\begin{array}{l}\text { Themes } \\
\text { Study }\end{array}$ & Elements & $f$ & Studies \\
\hline $\begin{array}{l}\text { Methodology } \\
\text { of teaching } \\
\text { in science of } \\
\text { hadith }\end{array}$ & $\begin{array}{l}>\text { Teacher-centred teaching } \\
>\text { Memorisation of matan } \\
>\text { Use tables and diagrams } \\
>\text { Lecturers act as muallim } \\
>\text { Student-centred teaching } \\
>\text { Material-centred } \\
\text { teaching } \\
>\text { Eclectic approach } \\
>\text { Four pedagogical skills of } \\
\text { the Prophet } \\
>\text { Assessment methods }\end{array}$ & 3 & $\begin{array}{l}\text { Sobali, A. M., Alias, N., Nor, Z. M., } \\
\text { \& Azmi, A. S. (2011), Ahmad, T., } \\
\text { \& Deraman, F. (2011), Yabi, S., } \\
\text { Kadri, S., Mohd Nor, Z., \& Mohd } \\
\text { Amin, M. F. (2017). }\end{array}$ \\
\hline $\begin{array}{l}\text { Student } \\
\text { learning } \\
\text { methods }\end{array}$ & $\begin{array}{l}>\text { Student acceptance } \\
>\text { Mental preparedness } \\
>\text { Emotional } \\
>\text { Active learning }\end{array}$ & 3 & $\begin{array}{l}\text { Abd Rahman, M. M., \& Asbullah, } \\
\text { Z. (2012), Yabi, S., Kadri, S., } \\
\text { Mohd Nor, Z., \& Mohd Amin, M. } \\
\text { F. (2017), Zin, S. M. M., Omar, H., } \\
\text { Ishak, M. A., Nasir, M. N., \& } \\
\text { Omar, N. (2019). }\end{array}$ \\
\hline $\begin{array}{l}\text { Scope of } \\
\text { teaching and } \\
\text { learning in } \\
\text { the science } \\
\text { of hadith }\end{array}$ & $\begin{array}{l}>\text { Teaching Aids } \\
>\text { Syllabus } \\
>\text { Core subject } \\
>\text { Textbook } \\
>\text { Credit hour }\end{array}$ & 3 & $\begin{array}{l}\text { Abd Rahman, M. M., \& Abd } \\
\text { Haliff, A. L. (2011), Abd Rahman, } \\
\text { M. M., \& Asbullah, Z. (2012), } \\
\text { Yabi, S., Kadri, S., Mohd Nor, Z., } \\
\text { \& Mohd Amin, M. F. (2017) }\end{array}$ \\
\hline
\end{tabular}

RQ3: What research methods have been used to research hadith studies in Malaysia?

Based on the analysis performed, there are two research approaches used that are qualitative and quantitative. As for the study's design, two types of design are used, namely survey and interview. Table 4 shows the study approach used.

Table 4: Approaches and design of the study

\begin{tabular}{|c|c|c|c|}
\hline Approaches & Design & $f$ & Studies \\
\hline Qualitative & $\begin{aligned}> & \text { Interview } \\
> & \text { Observation } \\
> & \text { Document } \\
& \text { analysis }\end{aligned}$ & 6 & $\begin{array}{l}\text { Sobali, A. M., Alias, N., Nor, Z. M., \& } \\
\text { Azmi, A. S. (2011); Ahmad, T., \& } \\
\text { Deraman, F. (2011); Yabi, S., Kadri, S., } \\
\text { Mohd Nor, Z., \& Mohd Amin, M. F. } \\
\text { (2017); Abd Rahman, M. M., \& Abd } \\
\text { Haliff, A. L. (2011); Abd Rahman, M. } \\
\text { M., \& Asbullah, Z. (2012); Zin, S. M. M., } \\
\text { Omar, H., Ishak, M. A., Nasir, M. N., \& } \\
\text { Omar, N. (2019) }\end{array}$ \\
\hline Quantitative & $\begin{aligned}> & \text { Review } \\
& \text { (Questionnaire) }\end{aligned}$ & 0 & \\
\hline Mix-method & $\begin{array}{l}>\text { Questionnaire } \\
>\text { Document } \\
\text { analysis }\end{array}$ & 1 & $\begin{array}{l}\text { Yabi, S., Kadri, S., Mohd Nor, Z., \& } \\
\text { Mohd Amin, M. F. (2017) }\end{array}$ \\
\hline
\end{tabular}


Based on the analysis conducted, there are three samples used in related studies namely, Public Higher Educational Institutions (IPTA), Private Higher Educational Institutions (IPTS) and no have a sample. Table 5 shows the sample of studies used.

Table 5: Sample Study

\begin{tabular}{|l|l|l|}
\hline Sample & $\boldsymbol{f}$ & Studies \\
\hline $\begin{array}{l}\text { Public Higher } \\
\begin{array}{l}\text { Educational Institutions } \\
\text { (IPTA) }\end{array}\end{array}$ & 3 & $\begin{array}{l}\text { Abd Rahman, M. M., \& Abd Haliff, A. L. (2011); Abd } \\
\text { Rahman, M. M., \& Asbullah, Z. (2012); Yabi, S., } \\
\text { Kadri, S., Mohd Nor, Z., \& Mohd Amin, M. F. (2017) }\end{array}$ \\
\hline $\begin{array}{l}\text { Private Higher } \\
\begin{array}{l}\text { Educational Institutions } \\
\text { (IPTS) }\end{array}\end{array}$ & 1 & $\begin{array}{l}\text { Zin, S. M. M., Omar, H., Ishak, M. A., Nasir, M. N., \& } \\
\text { Omar, N. (2019) }\end{array}$ \\
\hline No have any sample & 3 & $\begin{array}{l}\text { Sobali, A. M., Alias, N., Nor, Z. M., \& Azmi, A. S. } \\
\text { (2011); Ahmad, T., \& Deraman, F. (2011); Yabi, S., } \\
\text { Kadri, S., Mohd Nor, Z., \& Mohd Amin, M. F. (2017) }\end{array}$ \\
\hline
\end{tabular}

RQ4: What are the main findings from the study on the science of hadith studies in Malaysia?

The main findings of the related studies are based on the study's objectives, as shown in Table 6.

Table 6: Main Findings of the Studies

\begin{tabular}{|c|c|c|}
\hline Studies & Objective & Main Findings \\
\hline $\begin{array}{l}\text { Sobali, A. M., Alias, } \\
\text { N., Nor, Z. M., \& } \\
\text { Azmi, A. S. (2011) }\end{array}$ & $\begin{array}{l}\text { Teaching methods and } \\
\text { a study following this } \\
\text { science. The extent to } \\
\text { which this material way } \\
\text { or method produces } \\
\text { students who are } \\
\text { proficient in Ulum al- } \\
\text { Hadith. This paper will } \\
\text { try peeling the habit of } \\
\text { studying the science of } \\
\text { Ulum al-Hadith then } \\
\text { and now, the need for } \\
\text { deep understanding } \\
\text { and integrity of } \\
\text { knowledge through } \\
\text { material memorisation. } \\
\text { Methodology of } \\
\text { teaching and learning } \\
\text { by memorisation of } \\
\text { matan. }\end{array}$ & $\begin{array}{l}\text { After observing the needs and having } \\
\text { experience as a teacher of Ulum Hadith, the } \\
\text { author argues that the teaching method of } \\
\text { Ulum Hadith requires memorisation, } \\
\text { informing students who truly understand } \\
\text { Ulum Hadith and the use of textbooks as } \\
\text { additional references can strengthen } \\
\text { understanding of the syllabus. This is } \\
\text { because the technique of memorising } \\
\text { material is seen to be able to preserve the } \\
\text { definitions in Ulum Hadith with the } \\
\text { permanence of the memorised } \\
\text { information. This approach is also based on } \\
\text { the tradition of hadith scholars in the past } \\
\text { who mastered the science of hadith by } \\
\text { memorising matan. }\end{array}$ \\
\hline $\begin{array}{l}\text { Ahmad, } \quad \text { T., \& } \\
\text { Deraman, F. (2011) }\end{array}$ & $\begin{array}{l}\text { Highlight examples of } \\
\text { tables and diagrams to } \\
\text { interest students } \\
\text { studying the Hadith } \\
\text { Science course. }\end{array}$ & $\begin{array}{l}\text { The use of tables and diagrams is able to } \\
\text { make the course content the complex turns } \\
\text { out to be simple and eye-catching. }\end{array}$ \\
\hline
\end{tabular}




\begin{tabular}{|c|c|c|}
\hline & $\begin{array}{l}\text { Review the examples, } \\
\text { an attempt to write the } \\
\text { books of Mustalah al- } \\
\text { Hadith using mind } \\
\text { maps in the form of } \\
\text { tables and diagrams. }\end{array}$ & $\begin{array}{l}\text { Teaching and writing methods using tables } \\
\text { and diagrams. }\end{array}$ \\
\hline $\begin{array}{l}\text { Yabi, S., Kadri, S., } \\
\text { Mohd Nor, Z., \& } \\
\text { Mohd Amin, M. F. } \\
\text { (2017) }\end{array}$ & $\begin{array}{l}\text { To study the teaching } \\
\text { approaches applied to } \\
\text { the Ulum Hadith } \\
\text { subjects offered at } \\
\text { higher education } \\
\text { institutions in Malaysia } \\
\text { and identify } \\
\text { opportunities to } \\
\text { reinforce the Ulum } \\
\text { Hadith teaching } \\
\text { approach. }\end{array}$ & $\begin{array}{l}\text { The findings show that among the } \\
\text { approaches in the teaching and learning of } \\
\text { the Ulum Hadith subjects in higher learning } \\
\text { institutions are lecturers should act as } \\
\text { muallim, producing meaningful learning } \\
\text { with student-centred teaching, using an } \\
\text { eclectic approach that combines all or part } \\
\text { of the features of a method into new } \\
\text { methods, using tables and diagrams in } \\
\text { learning, mastering the four pedagogical } \\
\text { skills of the Prophet, and implementing } \\
\text { active learning. }\end{array}$ \\
\hline $\begin{array}{l}\text { Abd Rahman, M. } \\
\text { M., \& Abd Haliff, A. } \\
\text { L. (2011) }\end{array}$ & $\begin{array}{l}\text { To review the extent to } \\
\text { which the study of } \\
\text { hadith finds a place in } \\
\text { Islamic IPT in the } \\
\text { Middle East. Whether } \\
\text { the subject of Ulum } \\
\text { Hadith is a core subject } \\
\text { for a university/faculty } \\
\text { based on Islam or a side } \\
\text { subject. Second, how } \\
\text { many hours are } \\
\text { allocated for the } \\
\text { subject of Ulum } \\
\text { Hadith? Third, what is } \\
\text { the book that is the } \\
\text { main reference in the } \\
\text { subject of Ulum Hadith. } \\
>\text { Scope of teaching } \\
\text { and learning } \\
>\text { Syllabus Core Subjects } \\
>\text { Textbook } \\
\text { Credit Hour }\end{array}$ & $\begin{array}{l}\text { The reality of studying Ulum Hadith in } \\
\text { university has transformed. This } \\
\text { transformation has given an advantage to } \\
\text { the study of hadith in general and the study } \\
\text { of Ulum Hadith or Mustalah al-Hadith in } \\
\text { particular. This can be seen when this } \\
\text { knowledge has been made a core or } \\
\text { compulsory subject either at the university, } \\
\text { faculty or department level. This } \\
\text { development illustrates the importance of } \\
\text { this knowledge that must be introduced to } \\
\text { students at the university level. } \\
\text { Reference materials in this field are also } \\
\text { seen to increase through the writings } \\
\text { produced by scholars. This is also a factor } \\
\text { that allows the knowledge of Ulum Hadith } \\
\text { to be at its current level. The current } \\
\text { generation needs to improve efforts such } \\
\text { as the coordination of time allocation so } \\
\text { that this knowledge can continue to be } \\
\text { learned and understood well. }\end{array}$ \\
\hline $\begin{array}{l}\text { Abd Rahman, M. } \\
\text { M., \& Asbullah, Z. } \\
\text { (2012) }\end{array}$ & $\begin{array}{l}\text { To review the extent to } \\
\text { which the study of } \\
\text { hadith finds a place in } \\
\text { Islamic IPT in Malaysia. }\end{array}$ & $\begin{array}{l}\text { The study of hadith is increasingly gaining } \\
\text { attention and high acceptance among } \\
\text { students. }\end{array}$ \\
\hline
\end{tabular}




\begin{tabular}{|c|c|c|}
\hline & $\begin{array}{l}\text { Whether the subject of } \\
\text { Ulum Hadith is a core } \\
\text { subject for a } \\
\text { university/faculty } \\
\text { based on Islam or a side } \\
\text { subject. Second, how } \\
\text { many hours are } \\
\text { allocated for the } \\
\text { subject of Ulum al- } \\
\text { Hadith? Third, what is } \\
\text { the book that is the } \\
\text { main reference in the } \\
\text { subject of Ulum al- } \\
\text { Hadith. }\end{array}$ & $\begin{array}{l}>\text { Scope of teaching and learning } \\
\text { Syllabus } \\
>\text { Core Subjects } \\
>\text { Textbook } \\
>\text { Credit Hour }\end{array}$ \\
\hline $\begin{array}{l}\text { Yabi, S., Kadri, S., } \\
\text { Mohd Nor, Z., \& } \\
\text { Mohd Amin, M. F. } \\
\text { (2017) }\end{array}$ & $\begin{array}{l}\text { To study the teaching } \\
\text { and learning of Ulum } \\
\text { Hadith courses at } \\
\text { USIM, UIAM and UKM, } \\
\text { and to identify teaching } \\
\text { methods and } \\
\text { techniques practised by } \\
\text { the lecturers of Ulum } \\
\text { Hadith courses. }\end{array}$ & $\begin{array}{l}\text { Component 1: Teaching methods used by } \\
\text { lecturers: three approaches to the teaching } \\
\text { method: teacher-centred teaching, } \\
\text { student-centred teaching, and material- } \\
\text { centred teaching. } \\
\text { Component 2: Student learning methods. } \\
\text { Component 3: Student Acceptance of the } \\
\text { Hadith Ulum Course. } \\
\text { There are some differences between USIM, } \\
\text { UIAM and UKM in Ulum Hadith course } \\
\text { offered, the use of the language of } \\
\text { instruction in the teaching and learning } \\
\text { Ulum Hadith, and lecturers' teaching } \\
\text { methodology. }\end{array}$ \\
\hline $\begin{array}{l}\text { Zin, S. M. M., Omar, } \\
\text { H., Ishak, M. A., } \\
\text { Nasir, M. N., \& } \\
\text { Omar, N. (2019) }\end{array}$ & $\begin{array}{l}\text { To explore the mental } \\
\text { and emotional } \\
\text { preparedness of the } \\
\text { students who are } \\
\text { learning Ulum Hadith. }\end{array}$ & $\begin{array}{l}\text { Findings show that there are two main } \\
\text { factors resulting in an outstanding } \\
\text { achievement of this subject, namely (1) } \\
\text { mental preparedness and (2) emotional. In } \\
\text { short, there are five methods in the mental } \\
\text { preparedness and five factors that } \\
\text { influence students' emotions. Therefore, } \\
\text { these findings are hoped to improvise } \\
\text { student's achievement in studying Ulum } \\
\text { Hadith. }\end{array}$ \\
\hline
\end{tabular}

\section{Discussion}

Based on the findings of this study, it is found that there are three main themes in the study related to the science of hadith studies. The themes are to identify the teaching methodology, explore the student learning method and explore the scope of teaching and learning in the science of hadith. These three themes have their own sub-theme in exploring the theme, which is a construct for their study. As for the theme of teaching methodology, the sub-theme involved is methods of delivery. These themes and sub-themes form the basis of studies (Sobali et al., 2011; Ahmad \& Deraman, 2011; Yabi et al., 2017). 
As for the theme of the student learning method, the sub-themes involved are selflearning. The studies involved are (Abd Rahman \& Asbullah 2012; Yabi et al., 2019; Zin et al., 2019). Whereas sub-theme for the scope of teaching and learning in science of hadith, two sub-themes are involved: syllabus and teaching plan. The studies involved in this theme are (Abd. Rahman \& Abd Haliff, 2011; Abd Rahman \& Asbullah, 2012; Yabi et al., 2019).

In the analysis of teaching and learning in the science of hadith studies, there are nine elements shown in the theme of teaching methods, namely, teacher-centred teaching memorisation of matan, use tables and diagrams, lecturers act as muallim, student-centred teaching, material-centred teaching, eclectic approach, four pedagogical skills of the prophet and assessment methods. These elements are stated by (Sobali et al., 2011; Ahmad \& Deraman, 2011; Yabi et al., 2017).

The theme that has the third most element is the element of student learning methods. In studies conducted by Abd Rahman \& Asbullah (2012); Yabi et al (2019); Zin et al. (2019), the elements involved were student acceptance, student learning methods, mental preparedness, emotional and active learning. While the theme of the scope of teaching and learning in the science of hadith has five elements: teaching aids, syllabus, core subject, textbook, and credit hour. These elements are expressed through studies by (Abd Rahman \& Abd Haliff, 2011; Abd Rahman \& Asbullah, 2012; Yabi et al., 2019).

The study's findings also found that many researchers used qualitative approaches rather than mix-method approaches in their studies of hadith science. Six studies using qualitative approaches are Sobali et al. (2011); Ahmad \& Deraman (2011); Yabi et al. (2017); Abd Rahman \& Abd Haliff (2011); Abd Rahman \& Asbullah (2012); Zin et al (2019). Only one study using mix-method approaches is (Yabi et al., 2019).

Based on the findings of this study, most previous studies used a sample of Public Higher Educational Institutions (IPTA) compared to Private Higher Educational Institutions (IPTS). Three studies are using a sample of Public Higher Educational Institutions (IPTA) namely (Abd Rahman \& Abd Haliff, 2011; Abd Rahman \& Asbullah, 2012; Yabi et al., 2019). Followed by one study using a Private Higher Educational Institutions (IPTS), Zin et al. (2019). While the study of Sobali et al (2011); Ahmad \& Deraman (2011); Yabi et al (2017) are not involving any sample.

The findings also show that all previous studies related to the science of hadith studies have achieved their objectives. The study of Sobali et al (2011) found that the teaching method of Ulum Hadis requires memorisation informing students who truly master Ulum Hadis in addition to the use of textbooks as additional references that can further strengthen the understanding of the syllabus. This is because the technique of memorising matan is seen to be able to remember the definitions in Ulum Hadith with permanence.

The study of Ahmad \& Deraman (2011) found that the use of tables and diagrams is able to turn complex course content into simple and engaging. The study of Yabi et al (2017) found that among the approaches in the teaching and learning of the Ulum Hadith subjects in university are lecturers should act as muallim, producing meaningful learning with studentcentred teaching, using an eclectic approach that combines all or part of the features of a method into new methods, using tables and diagrams in learning, mastering the four pedagogical skills of the Prophet and implementing active learning.

The study of Abd. Rahman \& Abd Haliff (2011) found that the study of hadith is gaining attention and high acceptance among university students in the middle east, especially related to syllabus, core subject, textbook and credit hour. Abd Rahman \& Asbullah (2012) 
found that the study of hadith is gaining attention and high acceptance among students in Malaysian universities, especially related to syllabus, core subject, textbook and credit hour.

The study of Yabi et al (2019) found some differences between USIM, UIAM and UKM in Ulum Hadith course offered, the use of language of instruction in the teaching and learning Ulum Hadith and the teaching methodology used by lecturers. The study of Zin et al (2019) found that two main factors are resulting in an outstanding achievement of this subject namely (1) mental preparedness and (2) emotional. In short, there are five methods in the mental preparedness and five factors that influence students' emotions. Therefore, these findings are hoped to improvise student's achievement in studying Ulum Hadith.

\section{Conclusion and Suggestion}

Overall, it is found that studies related to the science of hadith studies in Malaysia are still less than overseas studies. This science of hadith studies is essential in securing two basic needs: teaching and learning methods. As suggested, future studies may focus on constructs related to the science of hadith studies such as effectiveness, sampling in school, academic improvement and more. In addition, future studies on the science of hadith studies are also suggested using qualitative approaches to obtain different perspectives. In addition, future studies are also proposed to introduce new theories for the science of hadith studies in Malaysia.

\section{References}

Abd Rahman, M. M., \& Abd Haliff, A. L. (2011). Realiti pengajian ulum al-hadith di Institusi Pengajian Tinggi Timur Tengah: Suatu analisis. Jurnal Al-Quran Dan Al-Hadith: Seminar Antarabangsa Sunnah Nabawiyah: Realiti Dan Cabaran Semasa (MUSNAD) 01. (2011), 265-278.

Abd Rahman, M. M., \& Asbullah, Z. (2012). Realiti Pengajian Hadith di IPT Islam: Suatu Kajian di IPT Islam di Malaysia. Jurnal Al-Basirah, 2(2), 27-46.

Abdullah, R., bin Idris, M. I., \& Asni, F. (2020). Analisis Kehujahan H.adīth Dalam Pengkaedahan Sintaksis Arab Menurut Al-Suyuți:(Analysis Of Hadīth Argument In Arabic Syntax Methods According To Al-Suyuți). Journal Of Hadith Studies, 18-26.

Ahmad, T., \& Deraman, F. (2011). Penggunaan Jadual dan Gambarajah Di Dalam Penulisan Bagi Subjek Mustalah Al-Hadith. Jurnal Al-Quran Dan Al-Hadith: Seminar Antarabangsa Sunnah Nabawiyah: Realiti Dan Cabaran Semasa (MUSNAD) 01. (2011), 443-456.

Al-Azhari, S. M. J. U. (2017). Teaching Method of Prophet (SAAS) to His Followers: An Overview. Bangladesh Journal of Integrated Thoughts, 13(20).

Asni, F. A. H. M. (2017). Analysis of the concept of two Kalima Shahadah Al-Tauhid and AlRisalah according to the Qur'an and Al-Hadith'. International Journal of Academic Research in Business and Social Sciences, 7(10), 2222-6990.

Asni, F. A. H. M. (2017). THE PRACTICES OF WEAK (DAIF) HADITHS IN PRODUCTION OF ISLAMIC LAW FROM THE PERSPECTIVES OF HADITH STUDIES AND FATWA LEGISLATORS IN MALAYSIA. Al-Qanatir: International Journal of Islamic Studies, 7(1), 1-9.

Asni, F. A. H. M., Sulong, J., \& Ismail, A. (2017). Penggunaan hadis daif dalam fatwa mengenai wasiat di Malaysia serta langkah penyelesaiannya. Journal of Hadith Studies.

Eissa, M., \& Khalid, M. (2018). Development of Character and Life Skills through Islamic Methods of Teaching Acquired Science Subjects at Islamic International Schools in Malaysia. IIUM Journal of Educational Studies, 6(1), 3-17. 
Ismail, A., \& Asni, F. (2018). Manhaj Penulisan Al-Tirmidhi Terhadap Hadith-Hadith Abwab AlTafsir Dalam Kitab Al-Jami. Journal of Hadith Studies.

Saleem, M., \& Iqbal, H. S. (2019). Holy Prophet Hazrat Muhammad's Methods of Teaching and Its Relevance Today: A Historical Perspective. Al-Qalam, 24(1.), 72-83.

Sobali, A. M., Alias, N., Nor, Z. M., \& Azmi, A. S. (2011). Metodologi Pengajian Ulum Al-Hadith: Antara Keperluan Penghafalan Matan (Mustalah Al-Hadith) Dengan Pengajaran Secara Moden. Jurnal Al-Quran Dan Al-Hadith: Seminar Antarabangsa Sunnah Nabawiyah: Realiti Dan Cabaran Semasa (MUSNAD) 01. (2011), 331-340.

Webster, J., \& Watson, R. T. (2002). Analyzing the Past to Prepare for the Future: Writing a Literature Reviews. MIS Quartely, 26(2), xiii-xxiii.

Yabi, S., Ibrahim, N., Yusof, M. A., Amin, M. F. (2019). Students' Perception on Teaching and Learning of Ulum Hadith: A Comparative Study in Malaysian Higher Public Educational Institutions. Journal of Xi'an Shiyou University, Natural Science Edition, 16(12), 1-8.

Yabi, S., Kadri, S., Nor, M. Z., \& Amin, M. F. (2017). Pengajaran Kursus Ulum Hadith di Institusi Pengajian Tinggi Awam: Tinjauan Literasi Terhadap Pendekatan Pengajaran Masa Kini: Teaching the Science of Hadith Transmission Course in Public Higher Educational Institutions: A Literacy Review of Current Teaching Approaches. Journal of Ma'alim alQuran wa al-Sunnah, 13(14), 76-84. https://doi.org/10.33102/jmqs.v13i14.100

Zin, S. M. M., Omar, H., Ishak, M. A., Nasir, M. N., \& Omar, N. (2019). Pengaruh Kesediaan Mental dan Emosi Terhadap Kecemerlangan dalam Pembelajaran Ulum Hadis di Kalangan Pelajar: Kajian Kes di KUIS. Jurnal Pengajian Islam, 12(2), 179-191. 